\title{
Evaluating risk factors for protein-energy malnutrition in children under the age of six years: a case-control study from Iran
}

This article was published in the following Dove Press journal:

International Journal of General Medicine

16 August 2011

Number of times this article has been viewed

\author{
Afshan Sharghi' \\ Aziz Kamran ${ }^{2}$ \\ Mohammad Faridan ${ }^{3}$ \\ 'Department of Community \\ Medicine, Medical School, Ardebil \\ University of Medical Sciences, \\ Ardebil, ${ }^{2}$ Department of Public Health, \\ Faculty of Health, Isfahan University \\ of Medical Sciences, Isfahan, \\ ${ }^{3}$ Department of Public Health, Faculty \\ of Health, Lorestan University of \\ Medical Sciences, Lorestan, Iran
}

Introduction: Protein-energy malnutrition is one of the most important public health problems in Iran. It not only accounts for more than half of child mortality but can also produce somatic and mental impairment in survivors. The main aim of this study was to identify risk factors for protein-energy malnutrition in children under 6 years of age in Namin city.

Methods: This was a population-based, multicenter case-control study. Seventy-six children with malnutrition and 76 children without malnutrition were randomly recruited for case and control groups. The prevalence of risk factors in the two groups was compared. Data were gathered from a health center database and interviews with mothers and health workers. The Wilcoxon signed-rank test and logistic regression were used for data analysis.

Results: Female gender, poverty, short maternal height, and use of unhygienic latrines in the home were significantly associated with childhood malnutrition $(P<0.05)$.

Conclusion: The results of this study indicate four main factors (poverty, small maternal height, female gender, and absence of hygienic latrines in the home) as underlying factors in malnutrition of children under the age of 6 years.

Keywords: protein-energy malnutrition, children, risk factors, Namin

\section{Introduction}

Protein-energy malnutrition is one of the major health and nutritional problems in Iran, ${ }^{1}$ and accounts for $54 \%$ of mortality in children under the age of 5 years in developing countries. ${ }^{2}$ Based on reports by the World Health Organization, malnutrition has been recognized as creating the highest burden of disease in the world (16\% of all calculated disability-adjusted life years). ${ }^{3}$ Based on the 1999 Anthropometric and Nutrition Indicators Survey results, 800,000 children ( $15.4 \%$ of children under 5 years) have nutritional stunting, 540,000 children (10/9\%) are underweight, and 170,000 children (4/9\%) have wasting. This number comprises only moderate-to-severe malnutrition. If we add in the children with mild malnutrition, the magnitude of the problem becomes even greater. Malnutrition in children causes an increase in morbidity (higher incidence and severity of diseases, such as diarrhea) and mortality, and has an adverse effect on intellectual ability. In addition, it has psychological consequences and causes decrease in efficiency in adulthood. ${ }^{2}$

Kikafunda et al have divided the factors affecting childhood malnutrition in developing countries into three groups, ie, maternal factors, dietary factors, and socioenvironmental and economic factors. ${ }^{4}$

Reports of the contribution of each of the above risk factors to childhood malnutrition has been variable in different studies. This difference may be due to differences in socioeconomic, cultural, and environmental factors in the societies studied. ${ }^{5-8}$
Correspondence: Aziz Kamran Department of Public Health, Faculty of Health, Isfahan University of Medical Sciences, Isfahan, Iran

$\mathrm{Tel}+989141599416$

Fax +98 45I 55I 0057

Email a_kamranyen@yahoo.com 
By recognizing risk factors for childhood malnutrition, especially modifiable ones, planning to alleviate or modify these risk factors becomes possible, and ultimately the incidence of malnutrition and its consequences in children can be reduced. In this study, we evaluated risk factors for protein-energy malnutrition in children under the age of 6 years in the Namin township, which has a high rate of poverty and malnutrition.

\section{Methods and materials}

This was a multicenter nested case-control study. The Namin township is in Ardabil Province, one of the northernmost provinces in Iran. This township has a primary health care network consisting of six rural health centers and one urban health center, and 40 health houses, covering a population of 62,318 people. Based on the 2007 census, the number of children under the age of 6 years was 5769 , more than $90 \%$ of whom were covered by growth and vaccination monitoring within the regional health care network.

During 2007-2008, 82 children under the age of 6 years affected by protein-energy malnutrition (lower than $90 \%$ of normal childhood weight) were assessed at the health centers and health houses. Seventy-six of these children were included in the study, but six were withdrawn due to inability to cooperate or difficulty in accommodation. Therefore, 76 children were selected as the case group. For the control group, 76 further children were selected at random from children with normal growth who had been matched with the case group in accordance with demographic factors.

The necessary data were gathered by interviewing health care managers and the children's mothers using a researchbased questionnaire, the validity of which had been approved by five university faculty members specializing in nutrition and social medicine, and its reliability was confirmed by a Cronbach's alpha of 0.86 . Family files were used to collect data on maternal factors, growth monitoring, vaccination, and health care services received at the local health care unit. Statistical analysis was performed using SPSS (v 16; SPSS Inc, Chicago, IL), the paired $t$-test, Wilcoxon signed-rank test, and ultimately logistic regression analysis.

\section{Results}

Seventy-six children with malnutrition and 76 children with normal growth rates were included in the study as controls. Some characteristics of the case and control children are shown in Tables 1 and 2 .

Based on the data from Table 1, female gender, low birth weight, and a history of infectious disease in the previous month had a direct relationship with child malnutrition
Table I Distribution of child biologic factors in cases and controls ( $n=76$ in each group)

\begin{tabular}{|c|c|c|c|}
\hline \multirow[t]{2}{*}{ Variable } & \multicolumn{2}{|c|}{ Mean \pm SD n (\%) } & \multirow[t]{2}{*}{$P$ value } \\
\hline & Case & Control & \\
\hline Age (months) & $25.3 \pm 15.7$ & $24.7 \pm 15.5$ & 0.4 \\
\hline Gender (male) & $40(52.6)$ & $52(68.4)$ & 0.01 \\
\hline (female) & $36(47.4)$ & $48(31.6)$ & \\
\hline Birth weight (g) & $3040 \pm 471$ & $3422 \pm 525$ & $<0.001$ \\
\hline Birth age (day) & $27 I \pm 24.3$ & $274 \pm 15.7$ & 0.4 \\
\hline $\begin{array}{l}\text { Chronic disease } \\
\text { (positive) }\end{array}$ & $7(6.2)$ & $4(5.3)$ & 0.3 \\
\hline $\begin{array}{l}\text { Infectious disease } \\
\text { in previous month }\end{array}$ & $8(10.5)$ & $4(5.3)$ & 0.001 \\
\hline
\end{tabular}

Abbreviation: SD, standard deviation.

$(P<0.05)$, but there was no relationship between maternal age at child birth or presence of chronic disease and childhood malnutrition. Table 2 shows that, of the maternal factors, those that were directly related to childhood malnutrition were short maternal stature, maternal unemployment, and hyperemesis of pregnancy (Table 2). In addition, of the environmental factors, age close to that of the next oldest sibling, poor latrine hygiene in the home, passive exposure to cigarette smoke, use of kerosene instead of gas as the main domestic fuel at home were factors that had a significant relationship with childhood malnutrition (Table 3 ). The socioeconomic factors in this study which had a significant relationship with childhood malnutrition were migration during the previous 5 years and poverty in the family (Table 4). Ultimately, after logistic regression analysis, the only variables that maintained a significant relationship with childhood malnutrition were maternal height, female gender, poverty, and presence of unhygienic latrines in the home (Table 5).

Table 2 Distribution of maternal factors in cases compared with controls ( $n=76$ each group)

\begin{tabular}{|c|c|c|c|}
\hline \multirow[t]{2}{*}{ Variable } & \multicolumn{2}{|c|}{ Mean \pm SD n (\%) } & \multirow[t]{2}{*}{$P$ value } \\
\hline & Case & Control & \\
\hline Maternal age (years) & $26.7 \pm 5.4$ & $27.6 \pm 6.8$ & 0.4 \\
\hline Education (years) & $3.3 \pm 2.6$ & $3.6 \pm 2.7$ & 0.4 \\
\hline Weight (kg) & $60.8 \pm 10.9$ & $62.9 \pm 8.8$ & 0.2 \\
\hline Height (cm) & $154.0 \pm 6.4$ & $159 \pm 5.7$ & $<0.001$ \\
\hline Body mass index & $26.1 \pm 5.9$ & $24.7 \pm 4.1$ & 0.1 \\
\hline Depression score & $9.2 \pm 7.9$ & $8.2 \pm 7.1$ & 0.3 \\
\hline $\begin{array}{l}\text { Employment } \\
\text { (positive) }\end{array}$ & $6(7.9)$ & $15(19.7)$ & 0.02 \\
\hline $\begin{array}{l}\text { Decision power } \\
\text { (good) }\end{array}$ & $56(73.7)$ & $50(65.8)$ & 0.3 \\
\hline $\begin{array}{l}\text { Planned pregnancy } \\
\text { (positive) }\end{array}$ & $64(84.2)$ & $67(88.2)$ & 0.3 \\
\hline $\begin{array}{l}\text { Hyperemesis in this } \\
\text { pregnancy }\end{array}$ & $26(34.2)$ & $12(15.8)$ & 0.002 \\
\hline
\end{tabular}

Abbreviation: SD, standard deviation. 
Table 3 Distribution of environmental factors in cases and controls ( $n=76$ each group)

\begin{tabular}{|c|c|c|c|}
\hline \multirow[t]{2}{*}{ Variable } & \multicolumn{2}{|c|}{ Mean \pm SD n (\%) } & \multirow[t]{2}{*}{$P$ value } \\
\hline & Cases & Controls & \\
\hline $\begin{array}{l}\text { Age difference with } \\
\text { the older } \\
\text { sibling (months) }\end{array}$ & $49.3 \pm 28.9$ & $72.8 \pm 43.2$ & 0.03 \\
\hline $\begin{array}{l}\text { Average home } \\
\text { space for each } \\
\text { family member }\left(\mathrm{m}^{2}\right)\end{array}$ & $21 \pm 13$ & $21.5 \pm 10$ & 0.7 \\
\hline $\begin{array}{l}\text { Presence of a } \\
\text { hygienic latrine } \\
\text { in home }\end{array}$ & $47(6 \mid .8)$ & $56(73.7)$ & $<0.001$ \\
\hline $\begin{array}{l}\text { Availability of water } \\
\text { sanitation }\end{array}$ & 75 (98.7) & 75 (98.7) & I \\
\hline Passive smoking & $38(50)$ & $27(35)$ & 0.05 \\
\hline Main fuel (oil) & $67(88.2)$ & $62(81.6)$ & 0.05 \\
\hline $\begin{array}{l}\text { Main caregiver } \\
\text { (biologic mother) }\end{array}$ & $70(62.1)$ & $73(96.1)$ & 0.2 \\
\hline
\end{tabular}

Abbreviation: SD, standard deviation.

Table 4 Distribution of socioeconomic factors in cases and controls ( $n=76$ in each group)

\begin{tabular}{llll}
\hline Variable & \multicolumn{2}{l}{ Mean \pm SD n (\%) } & P value \\
\cline { 2 - 3 } & Cases & Controls & \\
\hline Household dependency ratio & $3.4 \pm 1.3$ & $3.4 \pm 1.2$ & 0.8 \\
Religion (Shiite) & $61(80.3)$ & $64(84.2)$ & 0.3 \\
Migration in previous five years & $8(10.5)$ & $2(2.6)$ & 0.0 I \\
Economic status (poverty) & $25(33)$ & II (I4.5) & $<0.00$ I \\
Parental education (year) & $4.4 \pm 2.5$ & $4.6 \pm 3.3$ & 0.7 \\
\hline
\end{tabular}

Abbreviation: SD, standard deviation.

Table 5 Logistic regression analysis of risk factors associated with childhood malnutrition

\begin{tabular}{llll}
\hline Variable & Wald test & P value & $\mathbf{9 5 \% ~ C l ~}$ \\
\hline Gender & 4.02 & 0.04 & $0.024-0.957$ \\
$\begin{array}{l}\text { Age difference with } \\
\text { previous child }\end{array}$ & 3.17 & 0.07 & $0.997-1.068$ \\
$\begin{array}{l}\text { Birth weight } \\
\text { Infectious disease }\end{array}$ & 0.22 & 0.63 & $0.998-1.000$ \\
in previous month & 3.78 & 0.06 & $0.976-1.017$ \\
$\begin{array}{l}\text { Presence of hygienic } \\
\text { latrine in home }\end{array}$ & 12.03 & 0.001 & $0.002-0.185$ \\
$\begin{array}{l}\text { Maternal height } \\
\text { Maternal hyperemesis }\end{array}$ & 0.1 & & \\
in pregnancy & 0.15 & 0.03 & $1.02-1.56$ \\
$\begin{array}{l}\text { Mother employed } \\
\text { Passive smoking }\end{array}$ & 0.07 & 0.69 & $0.2-11$ \\
$\begin{array}{l}\text { Migration in previous } \\
\text { 5 years }\end{array}$ & 0.16 & 0.68 & $0.07-11.29$ \\
$\begin{array}{l}\text { Main fuel (oil) } \\
\text { Economic status }\end{array}$ & 0.54 & 0.11 & $0.6-1.04$ \\
(poverty) & 2.1 & 0.54 & $0.15-61.5$ \\
\hline Abbreviation & & 0.01 & $1.08-1.72$ \\
\hline
\end{tabular}

Abbreviation: $\mathrm{Cl}$, confidence interval.

\section{Discussion}

The only relevant child-related biological factor following placement of data in the regression model was female gender, with male gender being considered a protective factor against malnutrition. Phengxay et al in Laos and Veghari and Gholam in Gorgan, Iran, reported male gender as a risk factor for malnutrition in children under 5 years, ${ }^{9,10}$ but in research by Setswe in Southern Africa, ${ }^{11}$ Sanghvi et al in Southern India, ${ }^{12}$ and Saadaat et al in Kashan, Iran, ${ }^{13}$ female gender was found to be more strongly related to childhood malnutrition. Considering the differences between these studies, it appears that gender is not a biological factor in malnutrition, but affects different stages of childhood growth via various cultural and social factors in different societies. One hypothesis is that Namin families dedicate more attention to the growth and nutrition of male children, and this warrants further study.

In contrast with expectations, the effect of birth weight was eliminated when the data were placed in a regression equation, even though an association has been reported between low birth weight and subsequent childhood malnutrition in other reviewed studies. ${ }^{5,12,14-16}$ It seems that maternal height as a predisposing factor affecting childhood birth weight is the strongest risk factor, and therefore the effect of birth weight was modified or neutralized in the regression equation.

This research establishes the importance of adequate female growth in childhood, because short maternal stature may itself be due to childhood malnutrition. Because maternal height has a significant association with birth weight, ${ }^{2}$ the mother may expose her child to malnutrition by delivering a low birth weight neonate, enabling this problem to continue from one generation to the next.

The effect of infectious disease during the past month was also eliminated after putting the data into a regression equation. It seems that repeated and long-term infection may cause childhood growth problems and malnutrition, which may be related to inadequate environmental health conditions. In this study, lack of availability of hygienic latrines at home, which indicates an undesirable environmental health environment, has been identified as an important risk factor for infectious diseases, so in regression equations, the effect of infectious disease during the past month has been modified and eliminated.

The effect of age difference with regard to the next eldest sibling was also eliminated in the regression model $(P=0.07)$. Considering the $P$ value, it seems the power of the study to evaluate this relationship would increase and become significant by increasing the sample size. In studies 
performed by Rayhan et al ${ }^{17}$ and Henry et $\mathrm{al}^{6}$ in Bangladesh, and Nojomi et al in Karaj, Iran, ${ }^{18}$ a significant association between age difference with regard to the next eldest sibling and childhood malnutrition was shown. In families with an age gap between siblings, children compete for parental care, and an increase in the disease rate and mortality in the younger children has been proven in these circumstances.

Sangvi et $\mathrm{l}^{12}$ have noted a relationship between hyperemesis of pregnancy and childhood malnutrition, although this may be due to a higher frequency of hyperemesis during pregnancy involving a female fetus. In this study, being pregnant with a female fetus was considered to be a primary factor in the relationship between hyperemesis of pregnancy and childhood malnutrition, and it was shown that the effect of hyperemesis of pregnancy was modified, but the effect of female gender of the child remained following regression analysis.

In studies by Mamoun et $\mathrm{al}^{19}$ and Henry et $\mathrm{al}^{6}$ in Bangladesh, as well as Setswe ${ }^{11}$ in southern Africa, no relationship was found between maternal education and malnutrition (similar to our study), but studies by Rayhan et al, ${ }^{17}$ Phengxay et al, ${ }^{9}$ and Rikimaru et $\mathrm{al}^{7}$ have reported a relationship between malnutrition and lower literacy status of the mother. The discordant results from various studies pertaining to the effect of maternal literacy on childhood nutritional status may be due to the general education and knowledge of mothers regarding child malnutrition and growth which, regardless of their education level, has a desirable effect on childhood growth. Among the environmental factors, only unsanitary latrines at home demonstrated a significant relationship with child malnutrition following regression analysis.

The relationship between unsanitary latrines in the home and childhood malnutrition has been shown in studies by El-Sayed et $\mathrm{al}^{20}$ in Egypt and Mitra et $\mathrm{al}^{21}$ in India. This may reflect the effect of poor environmental health, exposing the child to multiple infections, which has the long-term effect of growth problems and childhood malnutrition. Among the socioeconomic factors, a relationship between both poverty and family migration during the past 5 years and childhood malnutrition was demonstrated, but ultimately only poverty remained significant after regression analysis. This shows that migration was influenced by the family's economic status as an underlying and primary factor. This finding is in accordance with prior study results. ${ }^{17,21,22}$ In our study, the role of maternal height in malnutrition was indicated for the first time. One of the shortcomings of the present study was that the cases were only selected from children who had records in health care units, and other children who might have been suffering from malnutrition were not included in the study.

\section{Conclusion}

The results of this study indicated four main factors (poverty, maternal small height, female gender, and absence of hygienic latrines at home) as underlying factors in malnutrition of children under the age of 6 years. Therefore, the following interventions are recommended:

- Family education regarding the importance of nutrition and growth for girls, obtaining more nutritious and inexpensive foods, and appropriate distribution of food among family members

- Nutritional support for poor families and introducing such families to the Imam Khomeini Emdad committee

- Monitoring and maintaining standardization of latrines, and helping families to create a healthier environment

- Periodic monitoring of child growth, and early detection and treatment of children affected by malnutrition.

\section{Acknowledgment}

We sincerely thank the employees of the Namin Township Health Centers who helped us gather the data for this research.

\section{Disclosure}

The authors report no conflicts of interest in this work.

\section{References}

1. Park JE, Park K. Textbook of Preventive and Social Medicine. Volume 3. 17th ed. Tehran, Iran: Samt Publication; 2002.

2. de Oins M, Blossner M. WHO Global Database on Child Growth and Malnutrition. Geneva, Switzerland: World Health Organization; 1997.

3. World Health Organization. The World Health Report. Reducing Risks, Promoting Healthy Life. Geneva, Switzerland: World Health Organization; 2002.

4. Kikafunda JK, Walker AF, Collett D, Tumwine JK. Risk factors for early childhood malnutrition in Uganda. Pediatrics. 1998;102:45.

5. Anoop S, Saravanan B, Joseph A, Cherian A, Jacob KS. Maternal depression and low maternal intelligence as risk factors for malnutrition in children: A community based case-control study from South India. Arch Dis Child. 2004;89:325-329.

6. Henry FJ, Briend A, Fauveau V, Huttly SA, Yunus M, Chakraborty J. Gender and age differentials in risk factors for childhood malnutrition in Bangladesh. Ann Epidemiol. 1993;3:382-386.

7. Rikimaru T, Yartey JE, Taniguchi K, Kennedy DO, Nkrumah FK. Risk factors for the prevalence of malnutrition among urban children in Ghana. J Nutr Sci Vitaminol. (Tokyo). 1998;44:391-407.

8. Bloss E, Wainaina F, Bailey RC. Prevalence and predictors of underweight, stunting, and wasting among children aged 5 and under in Western Kenya. J Trop Pediatr. 2004;50:260-270.

9. Phengxay M, Ali M, Yagyu F, Soulivanh P, Kuroiwa C, Ushijima H. Risk factors for protein-energy malnutrition in children under 5 years: study from Luangprabang province, Laos. Pediatr Int. 2007;49:260-265. 
10. Veghari GR. Assessment of physical growth among the under 6 years children in rural area in Gorgan, Iran. Pak J Nutr. 2007;6:252-255.

11. Setswe $G$. Prevalence and risk factors for malnutrition among children aged 5 years and less in the Lefaragatlha village of Bophuthatswana. Curationis. 1994;17:33-35.

12. Sanghvi U, Thankappan KR, Sarma PS, Sali N. Assessing potential risk factors for child malnutrition in rural Kerala, India. JTrop Pediatr. 2001;47:350-355.

13. Saadaat Z, Masumeh A, Saberi F. Relationship of maternal BMI and sex with child malnutrition in children under 5. Faiz. 1984;9:57-62.

14. Ayatollahi SM. Identification of factors associated with the growth of schoolchildren in southern Iran. J Trop Pediatr. 1993;39:111-113.

15. Majlesi F, Nikpoor B, Golestan B, Sadre F. Growth chart study in children under 5 years old in rural area of Khoramabad province. Iran J Public Health. 2001;30:107-110.

16. Ronaghy HA, Caughey JE, Halsted JA. A study of growth in Iranian village children. Am J Clin Nutr. 1968;21:488-494.
17. Rayhan I, Khan S. Factors causing malnutrition among under five children in Bangladesh. Pak J Nutr. 2006;5:558-562.

18. Nojomi M, Tehrami A, Abadi SN. Risk analysis of growth failure in under-5-year children. Arch Iran Med. 2004; 7:195-200.

19. Mamoun N, Homedia S, Mabyou M, Hussan M, Muntasir A. Prevalence, types and risk factors for malnutrition in displaced Sudanese children. Am J Infect Dis. 2005;1:84-86.

20. El-Sayed N, Mohamed AG, Nofal L, Mahfouz A, Zeid HA. Malnutrition among pre-school children in Alexandria, Egypt. J Health Popul Nutr. 2001;19:275-280.

21. Mitra M, Tiwari A, Ghosh R, Bharati P. Dimensions and causes of child malnutrition: a study of preschool children of Raipur, Chhattisgarh, India. Anthropologist. 2004;6:247-252.

22. Islam MA, Rahman MM, Mahalanabis D. Maternal and socioeconomic factors and the risk of severe malnutrition in a child: a case-control study. Eur J Clin Nutr. 1994;48:416-424.
International Journal of General Medicine

\section{Publish your work in this journal}

The International Journal of General Medicine is an international, peer-reviewed open-access journal that focuses on general and internal medicine, pathogenesis, epidemiology, diagnosis, monitoring and treatment protocols. The journal is characterized by the rapid reporting of reviews, original research and clinical studies across all disease areas.

\section{Dovepress}

A key focus is the elucidation of disease processes and management protocols resulting in improved outcomes for the patient.The manuscript management system is completely online and includes a very quick and fair peer-review system. Visit http://www.dovepress.com/ testimonials.php to read real quotes from published authors.

Submit your manuscript here: http://www.dovepress.com/international-journal-of-general-medicine-journal 